\title{
EFEKTIVITAS PELATIHAN KEAJAIBAN DOA ISLAMI UNTUK MENINGKATKAN KESEJAHTERAAN EMOSI PADA SISWA SMK “X” DI YOGYAKARTA
}

\author{
Mumtaz Afridah ${ }^{1}$ \\ Hepi Wahyuningsih \\ Sumedi P. Nugraha
}

Program Studi Psikologi Profesi (S2) Universitas Islam Indonesia, Yogyakarta

\begin{abstract}
This experiment research aimed to examine the effect of Keajaiban Doa Islamic Training to improve emotional well-being of high school students in SMK "X" Yogyakarta. This research used non-randomized Pre and Posttest Control Group Design. Participants of this research were divided into two group, control and experiment groups. Keajaiban Doa Islamic Training was only gave to 14 respondents from experiment group and have identified as low emotional well-being score. They were asked to complete Simsek's emotional well-being scale (Cronbach's Alpha $=0,86$ ) before and after experiment. The result showed significancy $p=0.00(p<0.05)$ for the comparison level of $g$ score on experiment and control respondents at pre and posttest. It means that Keajaiban Doa Islamic Training could improved emotional well-being of high school students in SMK "X" Yogyakarta.
\end{abstract}

Keywords: Emotional Well-Being, Prayers, Keajaiban Doa Islami, Training

\begin{abstract}
ABSTRAK : Penelitian eksperimen ini bertujuan untuk mengetahui efektivitas pelatihan Keajaiban Doa Islami dalam meningkatkan kesejahteraan emosi pada 14 siswa SMK "X" Yogyakarta. Penelitian ini menggunakan desain eksperimen non-randomized pre and posttest control group design. Partisipan penelitian ini dibagi ke dalam dua kelompok, yaitu kelompok kontrol dan kelompok eksperimen. Pelatihan Keajaiban Doa Islami hanya diberikan kepada siswa SMA yang memiliki kesejahteraan emosi yang rendah. Partisipan diminta untuk mengisi skala kesejahteraan emosi milik Simsek (Cronbach's Alpha $=0,86$ ) sebelum dan sesudah pemberian perlakuan. Hasil dari penelitian ini menunjukkan signifikansi $\mathrm{p}=0,00(p<0.05)$ untuk perbandingan $g$ score pra dan pascates kelompok eksperimen dan kontrol. Hal ini berarti pelatihan Keajaiban Doa Islami dapat meningkatkan kesejahteraan emosioanl siswa SMK "X"Yogyakarta.
\end{abstract}

Kata Kunci : Kesejahteraan Emosi, Doa, Pelatihan Keajaiban Doa Islami

\footnotetext{
${ }^{1}$ Korespondensi mengenai artikel ini dapat melalui: amoratirza@gmail.com
} 
Kesejahteraan emosi menjadi topik utama dalam penelitian pada remaja beberapa tahun ini. Diener (1984) menjelaskan bahwa kesejahteraan emosi merupakan salah satu konstruk yang di dalamnya terkait dengan dua indikator afeksi, baik itu indikator positif maupun indikator negatif dari kesehatan mental. Diener, dkk., menambahkan (Ciarrochi, 2015) indikator dari bentuk kesejahteraan emosi adalah tingginya level emosi positif dan rendahnya level emosi negatif. Diener (1984) menjelaskan bahwa kesejahteraan emosi adalah salah satu dimensi dari kesejahteraan subjektif yang di dalamnya terkait dengan dua indikator afeksi, baik itu indikator positif maupun indikator negatif dari kesehatan mental. Indikator positif dari kesehatan mental termasuk di dalamnya adalah harga diri, kesejahteraan psikologis, dan ekstraversi, sementara indikator negatif dari kesehatan mental seperti depresi, kecemasan, dan neurotik.
Salah satu hal yang menyebabkan pentingnya kesejahteraan emosi adalah karena konstruk ini mampu mengembangkan kemampuan interpersonal dan intrapersonal pada siswa, khususnya siswa remaja (Seligmen dalam Hyunh, 2013). Lebih dari itu, Huebner (Hyunh, 2013) menambahkan bahwa tingginya tingkat kesejahteraan emosi yang positif pada diri siswa atau remaja dapat meningkatkan kemampuan dan performa akademik.

Realitas di lapangan menunjukkan hal yang berbeda. Kondisi remaja dari tahun ke tahun menunjukkan jauh dari kesejahteraan emosi yang positif. Rendahnya kesejahteraan emosi pada remaja ditunjukkan dengan banyaknya kasus kenakalan remaja. Pal (2011) menjelaskan bahwa rendahnya kesejahteraan emosi memiliki kaitan yang erat dengan kenakalan remaja. Data tentang kenakalan remaja menunjukkan peningkatan secara kuantitas dari tahun 2007 2009 dan 2013-2015.

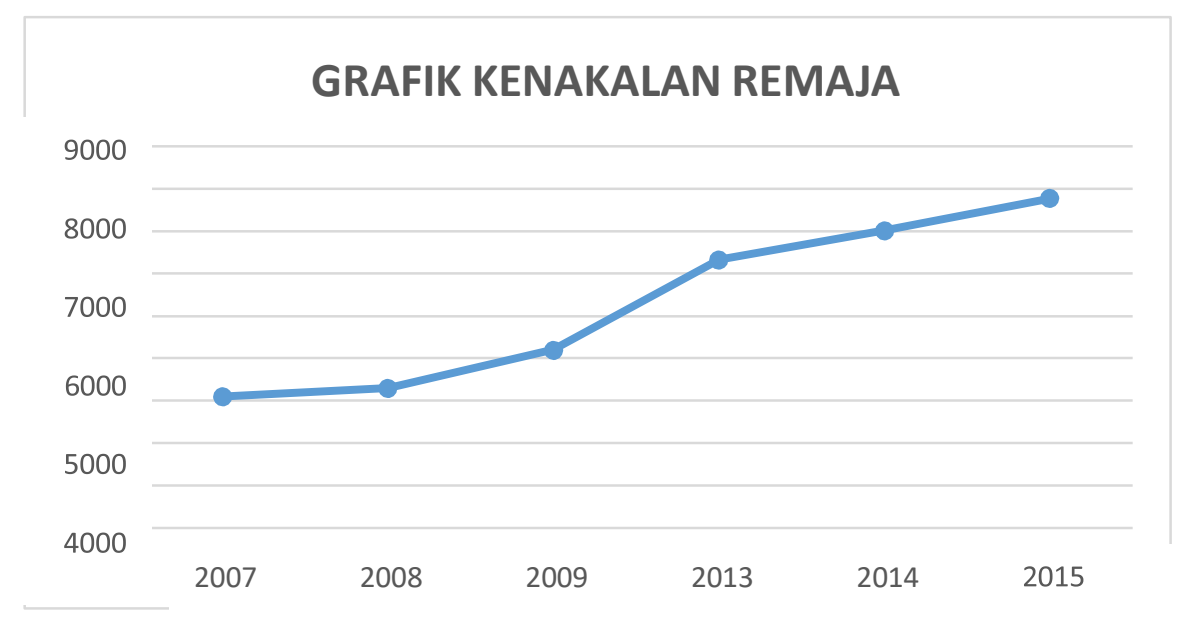

Grafik 1. Kenakalan remaja pada tahun 2007-2009 dan 2013-2015

Berdasarkan grafik tersebut tercatat pada tahun 2007 sekitar 3100 kasus kenakalan remaja, pada 2008 meningkat menjadi 3.300 kasus dan 2009 meningkat menjadi 4.200 kasus kenakalan remaja (Badan Pusat Statistik, 2010). Pada
2013 angka kenakalan remaja di Indonesia telah mencapai 6325 kasus, pada 2014 angka kenakalan remaja di Indonesia meningkat menjadi 7007 kasus dan pada 2015 meningkat menjadi 7762 kasus (Badan Pusat Statistik, 2016). 
Peningkatan itu tidak hanya secara kuantitas, laporan dari Badan Pusat Statistik (BPS) juga menunjukkan peningkatan secara kualitas, di mana kenakalan yang dilakukan remaja pada awalnya hanya berupa perilaku tawuran atau perkelahian antar teman, kini lebih berkembang sebagai tindak kriminalitas seperti pencurian, pemerkosaan, penggunaan narkoba hingga pembunuhan. Kenaikan kenakalan remaja dari segi kuantitas dan kualitas ini menunjukkan rendahnya kesejahteraan emosi yang dimiliki remaja Indonesia.

Kondisi rendahnya kesejahteraan emosi yang dimiliki siswa remaja tersebut dirasakan juga oleh siswa yang berada di SMK yang menjadi populasi dalam penelitian ini. Berikut grafik kesehatan sosial emosi yang diambil pada tahun 2016 pada siswa SMK "X" Yogyakarta kelas X yang saat laporan ini ditulis telah menginjak kelas XI:

\section{Skala SEHS}

110

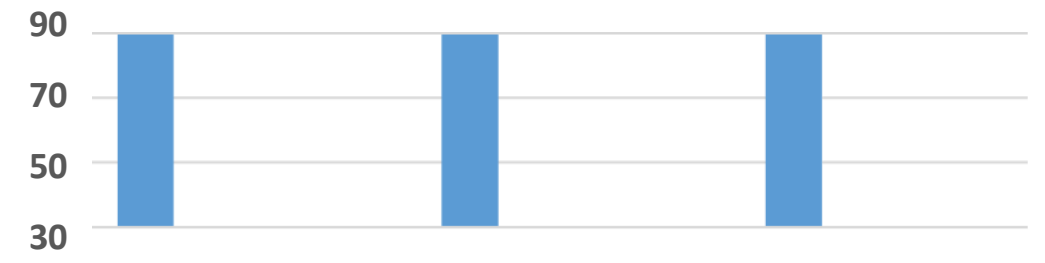

X TKJ A

X TPM

$X$ TKJ B

$\begin{array}{ll}\text { Rendah } & \text { : Skor CoVitaty } \leq 85 \\ \text { Rata-rata rendah } & \text { : Skor CoVitaty } 86-106 \\ \text { Rata-rata tinggi } & \text { : Skor CoVitaty 107-127 } \\ \text { Tinggi } & \text { : Skor CoVitaty } \geq 128\end{array}$

Grafik 2. Skala SEHS (Social Emotional Health Survey)

Grafik tersebut menunjukkan bahwa siswa SMK "X" memiliki kesehatan sosial emosi yang berada pada kategori rata-rata rendah, di mana skor pada seluruh siswa SMK "X" kelas X berada pada rentang 86106. Hasil wawancara wakil kepala sekolah SMK X menyebutkan bahwa rata-rata siswa memiliki beragam latar belakang persoalan. Ada yang terkait persoalan keluarga yang kurang harmonis, terlibat kasus narkoba, latar belakang ekonomi yang cenderung menengah ke bawah, kemampuan kognitif yang kurang, tidak bisa lolos ke SMA atau SMK Negeri, bahkan banyak dari mereka merupakan siswa pindahan dari sekolah lain karena kasus yang dialami mereka di sekolah sebelumnya.

Melihat banyaknya permasalahan kesejahteraan emosi pada siswa remaja baik di SMK "X" maupun secara umum, hal itu tidak lepas dari faktor-faktor yang berpengaruh pada konstruk ini. Salah satu yang mempengaruhi konstruk ini adalah rendahnya dukungan keluarga dan teman (Mamani \& Askari, 2013). Data yang diperoleh peneliti melalui observasi dan wawancara, beberapa siswa remaja menyatakan bahwa mereka merasa baik di rumah maupun sekolah sudah menjadi lingkungan yang kurang aman bagi mereka. 
Lingkungan sekolah yang awalnya menjadi tempat mereka memperoleh dukungan dari permasalahan tuntutan orangtua, telah berubah menjadi lingkungan yang penuh dengan ejekan dan tuntutan sosial. Mereka merasa harus menjadi baik dari segi apapun agar tidak mendapat penyudutan dari teman-teman. Lingkungan sekitar remaja baik berasal dari keluarga, teman, dan guru merupakan salah satu strategi koping dalam penyelesaian masalah remaja (Miller, 2012). Namun, lingkungan yang diharapkan menjadi faktor pendukung telah berubah menjadi ancaman bagi mereka.

Terlebih bahwa kasus perundungan meningkat pada beberapa tahun belakang. Data Badan Pusat Statistik (2016) tahun 2014 menyebutkan jumlah anak sebagai pelaku perundungan di sekolah mencapai 67 kasus dan meningkat menjadi 79 kasus pada 2015. Riset yang dilakukan LSM Plan International dan International Center for Research on Woman yang dirilis awal Maret 2015 menunjukkan fakta terkait kekerasan anak di sekolah. Terdapat $84 \%$ anak di Indonesia mengalami kekerasan di sekolah. Data ini menunjukkan bahwa lingkungan remaja sudah tidak ramah untuk dijadikan sumber pencarian bantuan. Ada penelitian yang menunjukkan bahwa kondisi lingkungan remaja yang penuh perundungan khususnya cyberbullying berkolerasi dengan rendahnya kesejahteraan emosi remaja (Cowie, 2013). Berdasarkan deskripsi di atas, penelitian ini fokus pada pencarian alternatif intervensi untuk meningkatkan kesejahteraan emosi remaja yang lebih menitik beratkan pada kapasitas yang dimiliki remaja, bukan pada dukungan lingkungan sekitar remaja.

Intervensi yang selama ini diberikan di SMK "X" Yogyakarta cenderung lebih mengarah pada sistem sekolah kaitannya dengan bimbingan konseling yang diberikan kepada siswa-siswa yang bermasalah, baik masalah umum maupun masalah yang berkaitan dengan emosi. Persoalannya, siswa
SMK "X" telanjur memiliki persepsi bahwa bimbingan konseling adalah tempat yang menyeramkan dan bukan tempat untuk didengarkan.

Referensi penelitian yang telah membahas intervensi untuk meningkatkan kesejahteraan emosi salah satunya adalah pelatihan fisik dengan olahraga, namun intervensi ini dirasa kurang cocok karena tidak semua remaja menyukai kegiatan olahraga serta kurang memperhatikan remaja yang memiliki keterbatasan fisik. Selain intervensi tersebut, terdapat pelatihan self monitoring pada guru dan siswa (Jembarwati, 2015) dan intervensi sistem perubahan positif lingkungan sekolah (Bond, dkk, 2004). Kedua intervensi ini pun dirasa lebih menitikberatkan pada lingkungan pendukung siswa. Penelitian lain menunjukkan bahwa harapan memberikan peningkatan afek positif remaja yang pada akhirnya meningkatkan kesejahteraan emosinya (Ciarrochi, dkk, 2015). Selain itu, spiritualitas juga memiliki pengaruh pada peningkatan kesejahteraan emosi (Sax, 2014).

Penelitian ini, berupaya untuk mengetahui efektivitas dari pelatihan Keajaiban Doa Islami terhadap kesejahteraan emosi pada siswa SMK. Harapan dari penelitian ini adalah adanya peningkatan skor kesejahteraan emosi setelah mendapat pelatihan Keajaiban Doa Islami. Keajaiban Doa Islami merupakan pelatihan yang berupaya untuk meningkatkan kemampuan seseorang dalam mengaplikasikan doa dengan cara lebih memaknai manfaat dari doa, mengetahui seluk beluk tentang doa, baik itu adab dan larangan dalam berdoa, hingga kemampuan untuk menghayati setiap doa yang mereka miliki serta upaya untuk berperilaku sesuai dengan harapan yang mereka panjatkan dengan maksud agar mengoptimalkan peran doa tersebut untuk kebermanfaatan pada diri mereka, khususnya kesejahteraan emosi mereka. 
Pelatihan ini didasarkan pada aspek-aspek doa menurut al-Qahtani (2011).

$$
\text { Al-Mahalli (2007) menjelaskan }
$$

bahwa doa adalah permohonan kepada Allah yang disertakan kerendahan hati untuk mendapatkan suatu kebaikan dan kemaslahatan yang berada di sisi-Nya. Shihab (2006) menambahkan bahwa pada dasarnya doa adalah bagian dari dzikir, di mana maknanya adalah permohonan, setiap dzikir kendati dalam redaksinya tidak terdapat permohonan, tetapi kerendahan hati dan rasa butuh kepada Allah yang selalu mengiringi pendzikir, sehingga menjadikan dzikir mengandung doa. Artinya, doa tidak hanya sebuah permohonan tetapi sekaligus mengingat Allah. Hal ini dikemukakan AlMahalli (2007) bahwa doa merupakan bagian dari dzikir dan mendekatkan diri kepada Allah.

Al-Qahtani (2011) mengungkapkan bahwa terdapat tiga aspek doa, yaitu : a) Lisan. Aspek lisan berkaitan dengan dasardasar pemahaman doa, melafalkan doa dan memahami arti, manfaat, dan tujuan dari doa yang dilafalkan laiknya berdialog dengan Allah; b) Hati. Aspek hati berkaitan dengan niat untuk melakukan berdasarkan keinginannya, yakin jika doanya akan diijabah (dikabulkan) dan memberikan manfaat untuk dirinya, meresapi makna dari doa yang dilafalkan, khusuk atau menggunakan perasaan ketika melafalkan doa; c) Amalan. Aspek amalan berkaitan dengan upaya seseorang untuk mengarahkan perilaku mereka ke arah tujuan yang diharapkan dan menjauhi segala hal yang menghalangi diijabahnya doa. Tujuan itu semata -mata merupakan ibadah kepada Allah Subhanahu Wa Ta'ala.

Doa pada dasarnya merupakan pengharapan manusia kepada Tuhan. Manusia diminta untuk berharap dan tidak berputus asa, seperti halnya tertulis dalam surat Al- A'raaf : 56 ,
"Dan janganlah kamu berbuat kerusakan di muka bumi, sesudah (Allah)memperbaikinya dan berdoa kepada-Nya dengan rasa takut (tidak akan diterima) dan harapan (akan dikabulkan). Sesunguhnya rahmat Allah amat dekat dengan orangorang yang berbuat baik" (Q.S. AlA'raaf : 56)

Dengan harapan yang telah dibentuk dalam perwujudan doa, Shihab (2006) menjelaskan bahwa seseorang yang beriman akan merasa lega, puas hati, dan tenang karena merasa bersama Allah Yang Maha Kuasa. Dengan demikian hal ini memberinya kekuatan batin dalam menghadapi rasa takut atau penyakit yang dirasakan. Setiap dzikir kendati dalam redaksinya tidak terdapat permohonan, tetapi kerendahan hati dan rasa butuh kepada Allah yang selalu mengiringi orang yang berdzikir, menjadikan dzikir mengandung doa (Shihab, 2016). Artinya, pada dasarnya doa tidak hanya sebuah permohonan tetapi sekaligus mengingat Allah. Di dalam Al-Qur'an Surat Ar-Ra'ad, ayat 28, disebutkan:

\section{"Ingatlah hanya dengan mengingat Allah-lah hati menjadi tenteram" (Q.S. Ar-Ra'ad (13) :28)}

Benson (2000) menjelaskan bahwa ketika seseorang terlibat secara mendalam dengan doa yang diulang-ulang, maka mereka ternyata akan memperoleh berbagai perubahan fisiologis, antara lain berkurangnya kecepatan detak jantung, menurunnya kecepatan napas, menurunnya tekanan darah, melambatnya gelombang otak dan pengaruh menyeluruh kecepatan metabolisme. Kondisi ini yang disebut Benson (2000) sebagai respon relaksasi dan ketenangan. Dengan meningkatnya ketenangan dan harapan, rasa cemas yang termasuk dalam afek negatif seseorang terhadap hidupnya pun berkurang. Individu 
akan cenderung memunculkan afek-afek positif seperti kebahagiaan dan kepuasan terhadap hidupnya.

\section{METODE PENELITIAN}

\section{Desain Penelitian}

Rancangan penelitian ini adalah non randomized pre and posttest control group design. Christensen (Seniati, Yulianto, \& Setiadi, 2005) mengemukakan bahwa desain non randomized pre and post test control group design adalah penelitian yang melibatkan dua kelompok responden: kelompok eksperimen dan kelompok kontrol namun pembagian kelompoknya tidak memiliki penugasaan acak atau tidak dilakuan secara acak. Desain ini masih menggunakan prates. Tingkat kesetaraan kelompok masih diperhitungkan.

Kelompok eksperimen terdiri atas 14 responden, akan diberikan prates dengan menggunakan skala kesejahteraan emosi yang merupakan adaptasi dari skala EWBS (Emotional Well Being Scale) milik Simsek (2011). Skala tersebut sudah diuji coba dan memiliki reliabilitas sebesar $r=0.86$ yang berarti memiliki reliabilitas yang tinggi. Setelah itu kelompok eksperimen diberi pelatihan Keajaiban Doa Islami, selanjutnya dilakukan pascates dengan skala kesejahteraan emosi kembali. Untuk kelompok kontrol, terdapat 15 responden dan dilakukan pengukuran prates dan pascates tanpa pemberian pelatihan. Pemberian pelatihan pada kelompok kontrol dilakukan menyusul setelah pengukuran pascates.

\section{Subjek Penelitian}

Subjek penelitian ini adalah siswa SMK dengan kriteria sebagai berikut: a) rentang usia 16-18 tahun; b) beragama Islam; c) Memiliki skor kesejahteraan emosi yang sedang, rendah, atau sangat rendah apabila diukur dengan skala kesejahteraan emosi milik Simsek (2011).

\section{Metode Pengambilan data}

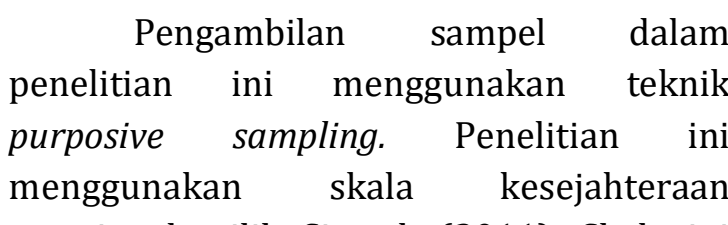
emosional milik Simsek (2011). Skala ini diadaptasi peneliti dengan menggunakan Bahasa Indonesia. Skala kesejahteraan emosional tersebut mengacu pada teori kesejahteraan emosional menurut Diener (1984). Skala kesejahteraan emosi tersusun atas 14 pertanyaan yang mengungkap dua aspek, yaitu: 1) kesejahteraan emosional positif, 2) kesejahteraan emosional negatif. Setiap butir aitem memiliki pilihan jawaban dengan rentang 1 hingga 5, skor 1 untuk pilihan jawaban "tidak pernah" dan skor 5 untuk pilihan jawaban selalu, skor 2 untuk pilihan "jarang", skor 3 untuk pilihan "sangat sering".

Pengukuran awal pada penelitian ini dilakukan pada saat melakukan screening test dengan menggunakan skala kesejahteraan emosi dari Simsek (2011). Hasil dari pengukuran awal ini juga dibandingkan dengan hasil pengukuran yang diberikan setelah rangkaian proses pelatihan berakhir. Pada pengukuran tindak lanjutan (follow up) responden tetap diminta untuk melakukan doa setelah proses pelatihan selesai dilakukan dan mencatatnya dalam lembar behaviour checklist yang telah diberikan. Skala kesejahteraan emosi diberikan kembali setelah proses latihan mandiri selama satu minggu selesai.

\section{Prosedur Intervensi}

Pemberian perlakuan berupa pelatihan Keajaiban Doa Islami dilakukan di aula sekolah para peserta. Pelatihan "Keajaiban Doa Islami" untuk siswa SMK disusun berlandaskan pada aspek doa 
menurut Al-Qahtani (2011), yaitu lisan, hati, dan amalan. Pelatihan berlangsung selama dua hari dengan jeda satu hari untuk mempraktekan materi yang mereka dapatkan. Rata-rata waktu yang digunakan setiap pertemuan adalah 100-150 jam. Peserta yang akan mengikuti pelatihan ini sebanyak 15 siswa yang memiliki kesejahteraan emosional yang rendah. Sebelumnya, peserta dibagi menjadi dua kelompok, kelompok kontrol dan kelompok eksperimen. Kelompok kontrol dan kelompok eksperimen dibedakan dari sekolah mereka.

Hari pertama acara pembukaan dan perkenalan antara fasilitator, ko fasilitator dan peserta, kemudian dilanjutkan penandatanganan informed consent dan dilanjutkan dengan penjelasan materi pelatihan. Materi pelatihan berkaitan dengan makna doa, manfaat doa, larangan dalam berdoa dan tata cara doa serta keajaiban doa yaitu peserta diberikan narasumber yang telah merasakan bahwa doa memberikan pengaruh yang luar biasa bagi kehidupan. Pelatihan diakhiri dengan pemberian tugas yang harus diamalkan oleh para peserta di rumah. Peneliti memberi jeda satu hari untuk para peserta melaksanakan tugas tersebut dan melakukan monitoring diri sampai pelatihan kedua berlangsung di hari berikutnya.

Hari kedua lebih mengarah pada penerapan ketiga aspek doa, dengan memberikan pemahaman tentang doa yang lebih spesifik yaitu doa untuk memberikan kebahagiaan dan ketenangan terlepas dari penderitaan, makna doa dan riwayat doa tersebut. Doa yang digunakan adalah doa taubat Nabi Yunus dan doa Nabi Ayub. Selain itu, peserta diajak untuk melakukan doa bersama dipandu oleh ustadz berdasarkan pada Al-Quran dan Hadist.

\section{Metode Analisis Data}

Analisis data menggunakan analisis kuantitatif. Analisis data untuk hipotesis menggunakan analisis Maan Whitney pada data yang tidak normal pada uji beda Independent sample $T$-Test. Analisis data menggunakan SPSS for Windows versi 16.

\section{HASIL PENELITIAN}

Berikut hasil analisis statistik dari data $g$ score saat prates dan pascates yang dilakukan pada kedua kelompok baik kelompok eksperimen dan kelompok kontrol .

Tabel 1. Uji Mann Whitney G Score I

\begin{tabular}{lr}
\hline Mann-Whitney U & 2.000 \\
$Z$ & -4.552 \\
Asymp. Sig. (2-tailed) & .000 \\
\hline
\end{tabular}

Berdasarkan uji nonparametrik menggunakan uji Mann Whitney pada data $G$ score pasca-pra kedua kelompok ditunjukkan signifikansi $\mathrm{p}=0.00(\mathrm{p}<0.05)$, maka dapat disimpulkan bahwa terdapat perbedaan G-score pasca-pra pada kelompok eksperimen dan kelompok kontrol. G score pada kelompok eksperimen lebih besar dibanding $G$ score pada kelompok kontrol. Hal ini menunjukkan adanya perubahan skor kesejahteraan emosi saat pascates pada kelompok eksperimen lebih besar dibandingkan pada kelompok kontrol. Hal ini juga menunjukkan hipotesis diterima bahwa pelatihan 
Keajaiban Doa Islami mampu meningkatkan skor kesejahteraan emosi.

Angka untuk rata-rata kelompok yang mendapat pelatihan dan kelompok yang tidak mendapat pelatihan juga berbeda, di mana rata-rata kelompok yang mendapat pelatihan lebih besar dibandingkan kelompok yang tidak mendapat pelatihan.
Hal ini menunjukkan bahwa skor kesejahteraan emosi yang dimiliki kelompok yang diberi pelatihan lebih besar dibanding kelompok yang tidak mendapat pelatihan. Dapat disimpulkan bahwa pelatihan Keajaiban Doa Islami mampu meningkatkan skor kesejahteraan emosi.

Berikut grafik perbandingan skor kesejahteraan emosi eksperimen dan kontrol

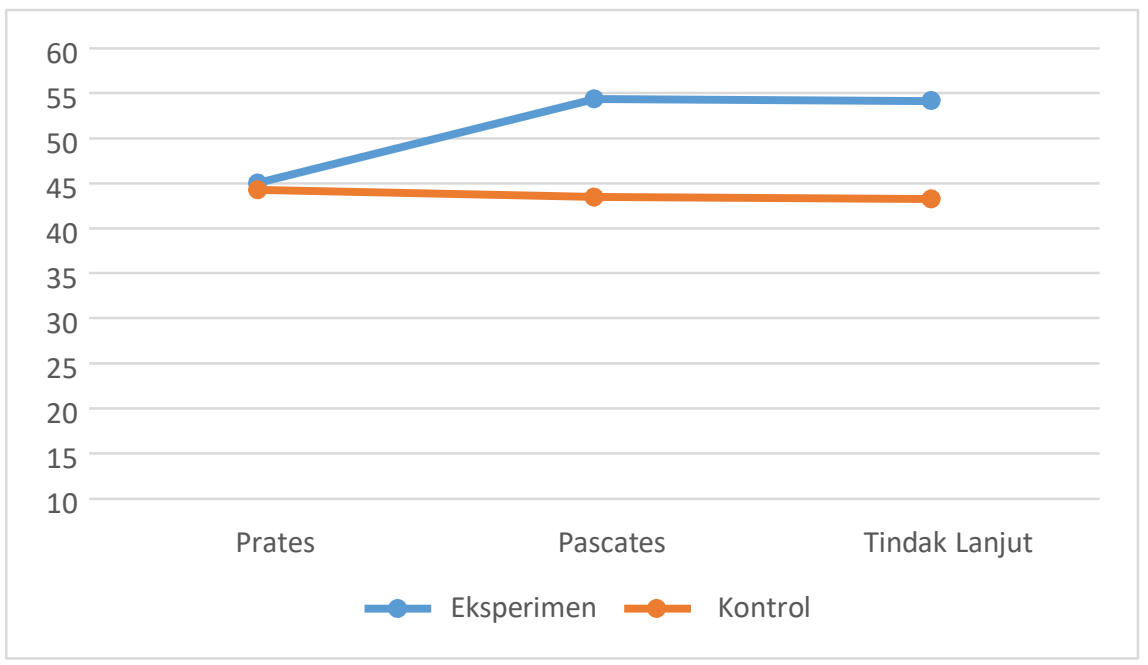

Grafik 3. Perbandingan skor Kesejahteraan Emosi Eksperimen dan Kontrol

Grafik di atas menunjukkan bahwa skor kesejahteraan emosi saat prates pada kelompok eksperimen dan kontrol tidak memiliki perbedaan signifikan. Sedangkan pada saat pascates, skor kesejahteraan emosi kelompok eksperimen meningkat sedangkan skor kesejahteraan emosi kelompok kontrol sedikit menurun. Hal ini menunjukkan efektivitas dari pelatihan Keajaiban Doa Islami pada peningkatan kesejahteraan emosi responden. Sementara saat tindak lanjut, keduanya tidak terdapat perubahan signifikan saat pascates.

Peneliti juga melakukan analisis menggunakan uji Friedman dengan tujuan untuk mengetahui perbedaan lebih dari dua kelompok sampel yang saling berhubungan yaitu, prates, pascates, dan tindakl lanjut. Berdasarkan hasil uji Friedman pada kelompok eksperimen saat prates-pascatestindak lanjut dimunculkan hasil sebagai berikut:

Tabel 2. Test Uji

Friedman

\begin{tabular}{lr}
\hline N & 14 \\
Chi-Square & 20.642 \\
Df & 2 \\
Asymp. Sig. & .000 \\
\hline
\end{tabular}

a. Friedman Test 
Tabel di atas menunjukkan bahwa Chi-Square $=20.642$ dan signifikansi $\mathrm{p}=0.00$ ( $\mathrm{p}<0.05$ ) artinya ada perbedaan yang signifikan skor kesejahteraan emosi kelompok eksperimen pada saat pra, pasca, dan tindak lanjut. Di mana skor kesejahteraan emosi lebih besar saat pascates dan tindak lanjut, yaitu dengan mean prates 45.1 dan 54.4 saat pascates serta 54.2 saat tindak lanjut. Hal ini berarti skor kesejahteraan emosi meningkat setelah diberikan perlakuan berupa pelatihan Keajaiban Doa Islami dan sedikit mengalami penurunan skor kesejahteraan emosi ketika follow up.

\section{PEMBAHASAN}

Penelitian ini bertujuan untuk mengetahui efektivitas dari Pelatihan Keajaiban Doa Islami terhadap peningkatan kesejahteraan emosi pada siswa SMK X. Hipotesis dalam penelitian ini adalah ada pengaruh pelatihan Keajaiban Doa Islami terhadap peningkatan kesejahteraan emosi pada siswa SMK X. Hipotesis tersebut terbukti dengan adanya perbedaan nilai $g$ score pada kelompok eksperimen dan kontrol dengan signifikansi $\mathrm{p}=0.00$. Perubahan $g$ score kelompok eksperimen saat pasca dan prates lebih besar dibandingkan pada kelompok kontrol. Hal tersebut menunjukkan bahwa pemberian perilaku berupa pelatihan Keajaiban Doa Islami mampu meningkatkan skor kesejahteraan emosi yang dimiliki siswa SMK X.

Penelitian ini mendukung penelitian-penelitian sebelumnya tentang doa. Penelitian yang dilakukan Gall, dkk (Schreiber \& Brockopp, 2014) pada pasien wanita penderita kanker, menunjukkan bahwa strategi koping religi mampu memprediksi distress dan kesejahteraan emosi. Perempuan yang memilih untuk melakukan kegiatan religi kepada Tuhan memiliki tingkat kesejahteraan emosi yang tinggi dan rendahnya distress. Selain itu disebutkan pula bahwa perempuan yang memohon syafaat langsung kepada Tuhan dilaporkan memiliki kesejahteraan emosi yang lebih tinggi sebelum operasi. Strategi koping religi yang dilakukan dalam penelitian Gall, dkk (Schreiber \& Brockopp, 2014) menjadi salah satu dasar dipilihnya pelatihan Keajaiban Doa Islami yang juga merupakan sebuah intervensi untuk melatih siswa dalam menerapkan sebuah strategi koping religius berupa doa dengan cara yang lebih baik.

Doa yang lebih baik dalam penelitian ini yaitu memberikan pemahaman yang mendalam tentang doa, melatihnya untuk menangkap masalah dan membentuk harapan, dan memberikan insight tentang kesesuaian antara harapan dan ikhtiar yang dilakukan oleh siswa. Selain itu memberikan insight jika terdapat ketidakpaduan antara harapan dengan perilaku yang dilakukan di mana mereka cenderung melakukan larangan terijabahnya doa, melatihnya untuk menghindari larangan-larangan yang menghalangi terijabahnya doa, serta melatih mereka untuk berdoa mendekati adab adab dalam berdoa.

Disamping sebagai sebuah bentuk dari strategi koping religi, pelatihan Keajaiban Doa Islami juga merupakan lanjutan dari penelitian yang dilakukan Ciarrochi, dkk (2015) di mana ia membuktikan bahwa sebuah harapan mampu meningkatkan kesejahteraan emosi. Ciarrochi, dkk (2015) menjelaskan bahwa ia membutuhkan sebuah intervensi untuk mengembangkan konsep harapan pada penelitian berikutnya. Pelatihan Keajaiban Doa Islami adalah bentuk intervensi yang mengembangkan konsep harapan melalui metode doa Islami. Pelatihan Keajaiban Doa Islami dibentuk dengan mempertimbangkan berbagai hal seperti yang diungkapkan Rivai 
(2004) yaitu materi yang disesuaikan dengan kebutuhan dari responden, metode yang disesuaikan dengan tujuan pencapaian pelatihan, kemampuan pelatih, sarana, tipe responden, melengkapi dengan evaluasi.

Pelatihan Keajaiban Doa Islami disesuaikan dengan kebutuhan remaja yang membutuhkan jawaban kaitannya dengan pertanyaan mengenai keyakinan religius yang mereka ikuti sejak mereka kecil (Santrock, 2007). Pelatihan ini dirancang dengan metode yang ringan walaupun materi yang diberikan adalah serius. Metode yang diberikan tidak hanya berupa ceramah tetapi juga pengisian lembar kerja, games, video, dan praktek, sehingga peserta yang tergolong remaja lebih merasa tertarik dengan pelatihan ini. Pelatih yang digunakan tidak hanya memahami agama, tetapi juga mampu membawakan materi yang dapat diterima remaja.

Berdasarkan atas pertimbangan pembentukan pelatihan menurut Rivai $(200$ 4), hasil evaluasi menunjukkan bahwa responden mayoritas memberikan respon yang positif terhadap pelatihan Keajaiban Doa Islami di mana respon peserta cenderung berada pada kategori tinggi. Ada juga beberapa peserta yang merespons lebih rendah dibandingkan peserta lainnya, yaitu peserta DF, RAH, dan KA. Ketiga peserta ini berjenis kelamin laki-laki dan berada dalam satu kelompok sekolah yang cukup sulit diatur. Namun kesan yang diberikan masih dalam kategori sedang.

Sikap yang positif terhadap pelatihan berpengaruh terhadap perilaku belajar siswa (Santrock, 2004). Hal ini terbukti dari hasil evaluasi di mana peserta yang memiliki sikap yang kurang positif terhadap pelatihan cenderung berperilaku yang kurang mengarah pada minat belajar yang positif. Hasil observasi minat belajar yang dimiliki DF, RAH, dan KA cenderung lebih rendah dibandingkan minat belajar peserta lain yaitu dengan skor 18, 19, dan 19.5 yang memang masih dalam kategori sedang, namun jauh berbeda dengan peserta lainnya yang mayoritas masuk dalam kategori tinggi.

Selain itu, minat dan motivasi yang positif berpengaruh terhadap keberhasilan belajar siswa (Santrock, 2004). Hal ini pun ditunjukkan pada ketiga siswa yang memiliki sikap dan perilaku yang kurang positif terhadap pelatihan di mana mereka mendapatkan skor yang lebih rendah dalam evaluasi belajar terkait dengan doa. Hasil evaluasi belajar pada DF, RAH, dan KA berada pada tiga posisi terendah dibanding peserta lain yaitu 57, 67, dan 58. Dengan perubahan dari prates dan pascates evaluasi belajar hanya 1 poin, sedangkan RAH masih cukup baik.

Ternyata, ketidakberhasilan pembelajaran pada DF, RAH, dan KA berpengaruh pada skor kesejahteraan emosi yang dimiliki ketiga siswa ini. Ketiga siswa ini hanya memiliki $g$ score pasca dan pra yang kecil. Pada siswa DF $g$ score yang dimilikinya adalah 2, dengan skor prates sebesar 47 dan skor pascates sebesar 49, sementara siswa RAH memiliki $g$ score yang lebih rendah dari DF di mana skor prates yang dimiliki RAH sebesar 45 dan skor pascates pun 45 . Sedangkan pada KA $g$ score yang dimilikinya adalah 3 di mana skor prates yang dimiliki KA adalah 45 dan pascatesnya adalah 48 .

Terlepas dari beberapa kekurangan yang ada, pada dasarnya penelitian ini telah menjawab prediksi hipotesis. Hal ini pun tidak lepas dari pertimbangan dalam melihat faktor yang mempengaruhi kesejahteraan emosi dari penelitian penelitian sebelumnya. Faktor yang dipilih dalam kaitannya dengan pelatihan Keajaiban Doa Islami adalah faktor religiusitas (Schreiber \& Brockopp, 2014) dan faktor harapan (Ciarrochi, dkk, 2015). 


\section{SIMPULAN DAN SARAN}

\section{Simpulan}

Berdasarkan penjelasan di atas dapat disimpulkan terdapat perbedaan signifikan dengan $\mathrm{p}=0.00(\mathrm{p}<0.05)$ antara $\mathrm{g}$ skor kesejahteraan emosi siswa yang diberi pelatihan Keajaiban Doa Islami dengan siswa yang tidak diberi pelatihan. Hal ini berarti hipotesis yang berbunyi "Pelatihan Keajaiban Doa Islami berpengaruh terhadap peningkatan skor kesejahteraan emosi SMK X" terbukti.

\section{Saran}

Berdasarkan pengalaman penelitian, peneliti memberi rekomendasi sebagai berikut: 1) bagi subjek penelitian, disarankan agar dapat terus menerapkan doa dalam kesehariannya serta mendekatkan diri pada perilaku yang selaras dengan harapannya; 2) bagi pihak sekolah, disarankan untuk mengingatkan kepada siswa untuk selalu dekat dengan TuhanNya, khusus untuk siswa muslim diingatkan untuk sholat berjamaah dengan para guru; 3) Penelitian selanjutnya disarankan untuk memperhatikan prakondisi dari subjek mereka untuk dapat mengetahui dari mana intervensi dapat dimulai, serta peneliti selanjutnya dapat meneliti faktor-faktor lain yang dapat meningkatkan kesejahteraan emosi yang dimiliki siswa remaja, seperti keluarga dan pertemanan. 


\section{DAFTAR PUSTAKA}

Al-Mahalli, A.N. (2007). Doa yang Didengar Allah. Yogyakarta: Mitra Pustaka.

Ash-Shidieqy, T.M.H. (2003). Dzikir dan Doa, Aspek Hukum dan Adab. Semarang: Pustaka Rizki Putra.

Al-Qahtani. (2011). Shurut al-du'a wa mawani al-ijabah: Fi dau'al alQur'an wa al-Sunnah. Riyad: Muassasah al-Jaris li al-Tawzi wa al-I'lan

Badan Pusat Statistik Indonesia. (2010). Profil Kriminalitas Remaja 2010. Jakarta: Katalog BPS. Diakses pada 25 Agustus 2016, dari http://www.bps.go.id Lhasil publikasi/flip 2011/44010 03/files/search/searchtext.xml

Badan Pusat Statistik Indonesia. (2016). Profil Kriminalitas Remaja 2016. Jakarta: Katalog BPS. Diakses pada 18 Agustus 2017, dari http://www.bps.go.id Lhasil publikasi/flip 2017/44010 03/files/search/searchtext.xml

Benson, H. (2000). Dasar-dasar Respon Relaksasi. (Terjemahan). Jakarta: Kaifa

Bond, L, dkk. (2004). The Gatehouse Project: can a multilevel school intervention affect emotional wellbeing and health risk behaviours? $J$ Epidemial Community Health. (58), 997-1003
Chiarrochi, J, dkk. (2015). Hope and emotional well-being: A six-year study to distinguish antecendents, correlates, and consequences. The Journal of Positive Psychology. 1-14

Cowie, H. (2013). The impact of cyberbullying on young people's emotional health and well-being. https://sites.google.com/site/costi c0801.

Diener, E. (1984). Subjective well-being. Psychology Bulletin. Vol-(95) 542575.

Hyunh, Q., Craig, W., Janssen, I., Pickett, W. (2013). Exposure to public natural space as a protective factor for emotional well-being among young people in Canada. BioMed Central Public Health. 13 (407)1-14

Jembarwati, 0. (2015). Self-monitoring untuk meningkatkan emosi peserta didik. Psychology Forum UMM. (3), 233-239

Mamani, A. W \& Askari, S. W. (2013) Expressed emotion and quality of parental relationship as predictors of emotional well-being in college students. International Journal of Psychology Research. 8 (2) 75-84

Miller, H.S. (2012). Major Coping Strategies. USA: The Henry Miller Group LLC

Pal, R. (2011). Psychological Dimension of Juvenile Delinquency. New Delhi: Readworthy 
review.Journal Cancer Survivor. (6) 82-94.

Rivai, V. (2004). Manajemen Sumber Daya Manusia Untuk Perusahaan. Jakarta: PT Raja Grafindo Persada.

Sax, L. J., \& Weintraub, D. S. (2014). Exploring the parental role in firstyear students' emotional wellbeing: Considerations by gender. Journal of Student Affairs Research and Practice. 51 (2), 113-127

Schreiber, J.A \& Brockopp, D.Y. (2012). Twenty-five years later-what do we know about religion/ spirituality and psychological wellbeing among breast cancer survivor? A systematic
Seniati, L., Yulianto, A., dan Setiadi, BN. (2011). Psikologi Eksperimen. Jakarta: Indeks

Shihab, M. Q. (2006). Wawasan Al-Qur'an tentang Zikir dan Doa. Jakarta: Lentera Hati.

Simsek, O. F. (2011). An intentional model of emotional well being: the development and initial validation of a measure of subjective wellbeing. Journal of Happiness Study. (12) 421-442. 
Mumtaz Afridah, Hepi Wahyuningsih E Sumedi P. Nugraha 